Greenstein himself went outside the United States on two occasions only-to a conference at the Papal Academy in Vatican City in 1949, and to Japan in 1956. He did, however, take a very prominent part in American scientific affairs. He was, for example, a past chairman of the Division of Biological Chemistry of the American Chemical Society and a member of the National Research Council's Committee on Biochemistry. He was on the editorial boards of Cancer Research and Archives of Biochemistry and Biophysics, while in recent years he was joint-editor with Prof. A. Haddow of "Advances in Cancer Research". At the time of his death he was just completing a major treatise on amino-acid chemistry. Among many formal acknowledgments of his work were included a Distinguished Service Award from the U.S. Government (1954) and the Hillebrand Prize of the American Chemical Society (1957).

Though modest about his own contribution, he was visibly proud of the work of his section, of his country and above all of his family. He will be greatly missed and all will sympathize with those near to him at their loss.

Dovglas Hamer

Dr. Greenstern's contributions extended widely in the fields of amino-acid, peptide and protein chemistry, and of nutrition. In the past few years he had devoted much effort to the elaboration of a completely soluble diet composed of chemically defined constituents ; and at the time of his death he was engaged (with M. Winitz), in the final stages of a major work on the chemistry of the amino-acids, which is to appear in three volumes, of which the first is now in the press. But apart from these, his contributions to cancer research alone would have more than sufficed to establish him among the leading biochemists of his time. He was an accomplished writer, and his "Biochemistry of Cancer" had, and has, immense influence, and proved a very significant stimulus to the subject as a whole.

Of his own work, two aspects were of particular importance ; first, his studies of the mechanism of production and the significance-of the dramatic decline in liver catalase activity which is observed in tumour-bearing animals; and secondly, his analysis and comparison of the distribution and activity of a host of enzyme systems in normal and cancer cells. In spite of the extreme difficulty and complexity of these problems, there gradually emerged a real and satisfying conclusion, namoly, that although tumours mostly possess the same enzymes as do norrnal tissues, qualitatively, none the less they tend, enzymatically, to converge to a common type, and hence show more resemblance to one another biochemically than to the normal tissues from which they arose.

All these, and many other contributions, embodied in upwards of 250 papers, brought him international acclaim. But we shall also remember him for his human qualities, and his combination of serious devotion with much courage and humour. Certainly $I$ have good cause to be grateful for many years of happy association with him; and Bethesda without him can never be quite the same. All who admired him will be glad to know that there has now been established, in his remembrance, a Jesse P. Greenstein Memorial Foundation, to be administered by a small committee of his colleagues, and which will, in cases where it is necessary or helpful, provide tuition and support during the years of undergraduate study in the arts or sciences, "to the son or daughter of a scientist who has made notable contributions to the medical, physical or biological sciences, and who is deceased".

Alex. Haddow

\section{Dr. Arthur Walton}

Dr. Arthur Walton, who died suddenly in Cambridge on April 6, was best known for his pioneering research in the field of sperm physiology and artificial insemination of farm animals. He was born in London, on March 16, 1897, of Scottish parents, and educated in Edinburgh, first at Daniel Stewart's College and later at the University, where he obtained in 1923 the degree of bachelor of science (agriculture). It was also in Edinburgh, at the Animal Breeding Research Department, where he received his early training in research methods and published, in 1924, his first paper, on "The Flocculation of Sperm Suspensions in Relation to Surface Charge". Keen interest in sperm physiology prompted Walton to move to Cambridge and take up research on animal reproduction. In 1926 appeared his first communication in Nature, on "Preservation of Mammalian Spermatozoa", a sub. ject which he expanded in the following year in his Ph.D. dissertation, and to which he devoted his special attention throughout his scientific life.

Among Walton's most outstanding contributions to the subject of sperm physiology was the first demonstration that ram semen, properly collected and stored, can be sent on long journeys to distant countries, to be used there for successful insemination of ewes; next, there were the experiments which proved that 'cold shock' can destroy the fertilizing ability of bull and ram spermatozoa. Of great scientific significance was his observation that the metabolic activity of ram and bull spermatozoa, particularly their respiration, is directly correlated with motility; and the discovery that respiring spermatozoa produce under certain conditions hydrogen peroxide which, in turn, is responsible for a gradually developing inhibitory effect on respiration and a decline in sperm motility. During his more recent investigations, Walton developed a novel and ingenious method of maintaining sperm alive for long periods, in a perfusion apparatus where nutrient substrates are fed continuously to a sample of semen and the toxic metabolites removed at the same time.

In addition to the work on spermatozoa, Walton has been keenly interested in various other aspects of reproductive physiology, including mating behaviour in animals and female fertility. He was the first to make detailed observations on ovulation in the rabbit, and to study the effect of maternal influences on the size of offspring in reciprocal crosses between large and small breeds of horses.

As a member of the University School of Agriculture and the scientific staff of the Agricultural Research Council, Walton spent nearly thirty years of his life in Cambridge, much of it in his laboratory at the Animal Research Station, in close association with many young research workers, always ready to help, to guide, and to advise. Although primarily concerned with physiological problems, Walton had also a profound knowledge in the field of general biology and agriculture. His contributions to agriculture, especially those which led to the establishment of the practice of artificial insemination in farm animals, were recognized in 1957 , by the award of 
the Medal "for outstanding research in agriculture" from the Royal Agricultural Society of England. Walton's many friends all over the world will mourn the untimely death of this outstanding scientific worker.

\section{J. HAMMOND \\ T. MANN}

\section{Dr. F. Tattersfield, O.B.E.}

Dr. Frederick Tatrersfield died at his home in Harpenden on May 1 at the age of seventy-eight. He may well be described as the founder of modern research on insecticides.

Dr. Tattersfield was born near Dewsbury in Yorkshire and went to Dewsbury Grammar School and the University of Leeds. From Leeds he graduated in chemistry with first-class honours. His first job was in association with the Leeds City Analyst, where for a number of years his work ranged over all the typical activities in such a department. In 1908 he joined a paint manufacturing firm; here his work was chiefly concerned with research on antifouling paints for ships.

Dr. Tattersfield went to France in the First World War as a founder member of the Friends' Ambulance Unit. He was invalided out in 1917, and went to Rothamsted Experimental Station, where he remained for the rest of his working life. He originally had a temporary appointment in the Chemistry Department, but he soon founded the present Department of Insecticides and Fungicides, of which he was the head for twenty-nine years.

Dr. Tattersfield's earliest work was concerned with the control of soil pests and he carried out some work on the structure - toxicity relationships of chemicals to wireworms. He also studied the factors influencing the decomposition of naphthalene in the soil and the effect of different rates of decomposition on its insecticidal action. $\mathrm{He}$ then proceeded to study the effect of a range of chemicals on the insects that attack the aerial parts of the plant, again attempting, so far as possible, to relate toxicity with structure in some systematic way. In the course of this work he discovered the outstanding ovicidal properties of dinitro-o-cresol, a substance which has been used as a winter wash for fruit trees ever since. At that time chemical manufacturers had little confidence in the development of effective synthetic organic chemicals for pest control, and Dr. Tatters. field in his search for highly biologically active chemicals turned his attention to plants. He examined a wide variety of plants for insecticidal activity, but his main work was done on the fish poison group, particularly Derris spp. and Tephrosia spp. and on Pyrethrum. His contributions on the isolation of the active principles of these plant products, the assessment of their insecticidal activity and their chemical estimation were quite outstanding. He studied many phases of the production and assay of pyrethrum as an insecticide and played a large part in the founding of the Kenya pyrethrum industry, an industry which has proved of the greatest value to the economy of the country.

During the course of his work, Dr. Tattersfield evolved precise methods of administering doses of chemicals to insects and introduced statistical procedures for the quantitative assessment of results.

The mere cataloguing of Dr. Tattersfield's contributions to knowledge on insecticides, substantial though they are, gives a very inadequate idea of what the subject owes to his influence which, for. tunately, was widely felt owing to his high international reputation. When he entered the subject the standard of work was very low and no serious attempt was being made to obtain reproducible quantitative results of known significance. Dr. Tattersfield insisted on the importance of precise quantitative data where the factors known to influence the results were standardized, so far as possible. and where both the design of the experiment and the results would satisfy accepted statistical criteria. In doing this he set standards which, over the course of years, have been accopted to the inestimable benefit of the subject.

Dr. Tattersfield was always a source of inspiration to his colleagues, to whom he was unfailingly kind and helpful. His justly acquired high reputation never changed his modest and unassuming personality, and his death will leave many of us with a deep sense of personal loss. He leaves a widow and one son.

C. Potter

\section{Dr. G. K. Groetzinger}

Dr. Gerhart K. Groetzinger, a principal scientist at the RIAS Division of the Martin Company, Baltimore, died on March 30 at the age of fifty-one. Born in Vienna, Austria, he received his doctorate in physics from the University of Vienna in 1931 and was a member of the faculty there before going to the United States in 1938.

Dr. Groetzinger has been associated as a faculty member, research worker and consultant with the University of Illinois, Ohio State University, the Enrico Fermi Institute for Nuclear Studies at the University of Chicago, the Lewis Laboratory of the National Advisory Committee on Aeronautics, and the Los Alamos Laboratory of the Atomic Energy Commission. Dr. Groetzinger joined RIAS in January 1956, and his work there since then had dealt primarily with solid state physics and cosmicray experiments performed in Earth satellites and high-altitude balloons. His work included some of the pioneer investigations of such fields as magnetophotoelectric effects in semi-conductors and the nuclear interactions of mu mesons.

\section{Mr. H. Curtis}

Mr. H. CuRTIs, production director of Leda Chemicals, Ltd., died on May 20 at the early age of thirty-nine.

Mr. Curtis graduated with honours at the Manchester College of Technology in 1941 in chemical engineering. After working during the War with chemical firms, he went to Sondes Place Research Institute in 1948 and in 1950 to Leda Chemicals, Ltd. He was appointed as a chemical engineer at a time when the firm was starting to manufacture fine chemicals. During his service with the firm, Mr. Curtis designed and constructed plant for the manufacture of quaternary ammonium compounds, cyanamide monomer and a range of other fine chemicals, notably rubber chemicals such as alkyl dithiocarbamates.

During the year 1953-54 Mr. Curtis went to Israel and worked on process development with Israel Mining Industries, Ltd. On returning he was elected a director of Leda Chemicals and its associated companies, Cunningham Smith, Ltd., and Lea Valley Chemicals, Ltd., becoming responsible for production and chemical engineering in these companies. 